\title{
対向右折車優先行動と右折専用車線設置が交通流に与える効果の比較*
}

\author{
鈴木 宏典 ${ }^{* 1}$ ，丸茂 喜高 ${ }^{* 2}$, 片山 硬 ${ }^{* 3}$
}

\section{Comparable Research on Effect of Prioritizing Right-Turn Vehicle and Right-Turn Pocket Installation on Traffic Flow}

\author{
Hironori SUZUKI ${ }^{* 1}$, Yoshitaka MARUMO and Tsuyoshi KATAYAMA \\ ${ }^{* 1}$ Nippon Institute of Technology, School of Engineering \\ Gakuendai 4-1, Miyashiro Town, Saitama 345-8501 Japan
}

This research attempts to evaluate the effect of prioritizing right-turn vehicle on traffic flow at a virtual signalized intersection. Traffic simulator calculates how much the prioritizing right-turn vehicle brings the effect on traffic efficiency, safety and environment around the intersection. It was assumed that the driver of on-coming thru traffic receives a-priori information how many vehicles are blocked by the right-turn vehicle. The ratio of prioritizing rightturn vehicle is given as stochastic probability density functions versus the number of blocked vehicles. The more blocked vehicles gives much higher probability of right-turn prioritizing. Numerical analysis showed that even low probability of prioritizing right-turn vehicle brings significant improvement of traffic throughout, safety and environment. Also, the effect is not very significant unless both inbound and outbound traffic execute right-turn vehicle prioritizing simultaneously. The effect was as significant as that by installing a general right-turn pocket and its special signal phase.

Key Words : Driver Assist, Man-Machine System, Human Interface, Active Safety, Human Engineering, Motivation

\section{1. 緒言}

運転支援システムによる直接的な事故防止の期待が高まる一方，これに伴うリスク補償行動 ${ }^{(1)} も$ 懸念されて いる。技術向上だけではなく，ドライバの安全意識も同時に高めなければ真に安全性の向上は期待できない(2) という立場に立つと, 事故の直接的な防止だけではなく, ドライバの動機づけに㗢きかけて安全意識を向上させ る事故防止対策も今後重要になると考えられる。

ドライバに対する動機づけは必ずしも安全に限ったことではなく，エコドライブ (3) や交通の円滑に対しても 有用性が高い. 例えば，自動車が交差点で右折する際，信号現示が青であれば対向直進車が優先となるため，右 折需要によっては, 右折車の後方に顕著な待ち行列が生じることもしばしば観測される。この右折待ち車両によ る交差点渋滞を回避するために，一般的に，右折専用車線や右折専用現示を設定するなど，インフラ側からの対 策を行う場合が多い. しかしながら，地理的な制約やコストの問題等からこれが実現不可能な場合もあり，現状 では，右折待ち車両による交通渋滞が避けられない交差点も存在している。そこで筆者らは，特に交通の円滑を 実現するドライバの動機づけに着目し，「直進車優先」という現状の運用方法に対して，敢えて対向直進側のド ライバが右折車に通行権（right-of-way）を譲る「利他的運転」に着目し，右折待ち車両が原因となる交通混雑 に対してどのような効果があるか検証を試みてきた ${ }^{(4)}$.

これまでの仮想交差点での解析で，右折車を優先する行動は交通の円滑を改善し，安全を向上させ，環境負荷

* 原稿受付 2012 年 2 月 13 日

*1 正員, 日本工業大学 工学部（干345-8501 埼玉県南埼玉郡宮代町学園台 4-1）

*2 正員, 日本大学 生産工学部（广275-8575 千葉県習志野市泉町 1-2-1）

*3 正員, 久留米工業大学 工学部（广830-0052 福岡県久留米市上津町 2228-66）

E-mail: viola@nit.ac.jp 
の低減に貢献することが明らかになりつつある ${ }^{(4)}$. しかしながら，現在までの研究では，ある実際の交差点を対 象として，かつ実測した交通需要などのデータのみで解析を行ったに過ぎないため，その評価結果は限定的で一 般的ではなかった。 また，右折車を優先させる行動のモデリングは右折待ちの車両によってブロックされている 台数には依存せず，譲るか譲らないかのみの一定值であることなどから，得られた結果は必ずしも一般的とは言 えない部分があった。さらに, 右折車優先行動が一般的な右折専用車線 (右折車線) や右折専用現示（青矢現示） との比較がなされていないため，その効果の相対的な位置づけが明確ではなかった。

そこで本稿では，対向直進車のドライバに対して右折車による待ち台数の情報が与えられると仮定し，この情 報に基づいた右折車優先行動が交通の円滑，安全，環境に与える効果を評価する。この評価には，譲りやすさの 個人差を含め，ぞのような譲り方でどの程度の効果が現れるか，仮想の信号交差点と仮想のデータで感度分析を 行うこととした。これに加え，右折車線及び青矢現示設置による効果が，右折優先行動による効果と比較してど の程度かについても明らかにすることとした。右折車優先行動の効果が相対的にどの程度であるか定量的な比較 検討を行うことにより，従来の土木・交通工学的なインフラ改良型の対策に対して，右折車優先行動の位置づけ が明確になることが期待される。さらに，上下線のいずれか一方しか右折車優先行動を行わない場合の検討も行 い，譲る側と譲られる側の特徴を把握することとした。

\section{2. 仮想交差点と交通シミュレータ入力値の設定}

本研究では交通シミュレータを用いるが，交通流を扱うシミュレーションには，いくつかの方法が考えられる. 例えば，市販の交通流シミュレータ (5) を用いると，右折車の優先行動などの再現が困難であり，セル・オート マトンによりモデリングを行う方法 ${ }^{(6),(7)}$ では，右折車優先のモデリングは可能であるが，現実の交通現象との 比較において，その妥当性が示されていない，また，OVモデルによって交通流をモデリングする方法 ${ }^{(8)}$ も考え られるが，理学的な交通流の変動特性を示したもので，工学的に交通流対策の効果等を論じる内容とは質が異な り，そのモデルの現況再現性にも課題が残る。そこで本研究では評価結果の妥当性を可能な限り保証するため, 筆者の一人が開発し，文献 (9) に基づいて既に検証を済ませたミクロ交通シミュレータを用いることとする.

\section{$2 \cdot 1$ 仮想交差点の設定}

右折車線を設けない場合は，図 1(a)のように主道路は片側 1 車線の対面通行とし，右折待ち車両が存在して も直進車両のすり抜けはできない仮想の交差点とする。右折車線を設ける場合は，図 1(a)の条件を変えずに図 1(b) のように，車線長 $20 \mathrm{~m}$ の右折車線を設ける。いずれの場合も，交通シミュレータ上で上下線とも交差点の 上流 $200 \mathrm{~m}$ まで道路リンクを設け，リンクとノードで構成されるネットワーク上に交通流を再現する。

\section{$2 \cdot 2$ 交通シミュレータ入力值の設定}

(1) 交通需要

上下線共に，250，500，1000，1500，1750vphの 5ケースの交通需要を発生させ，交通需要の変化に伴う評 価結果の感度を調べることとした。尚，単位の vph は台／時である.

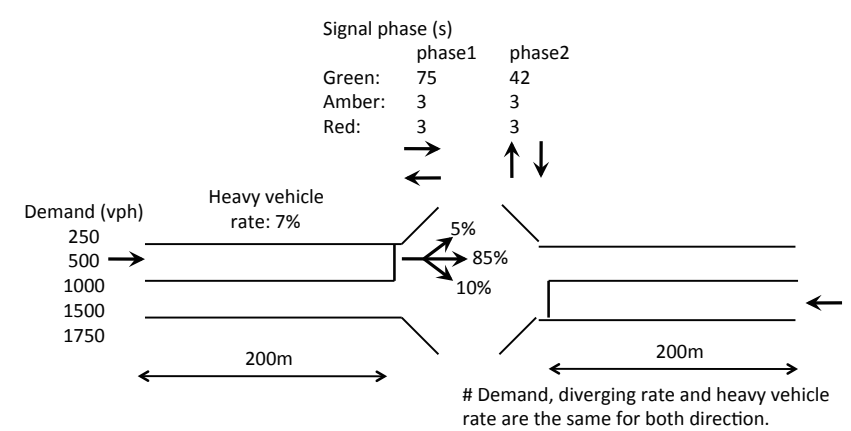

(a) Without right-turn pocket

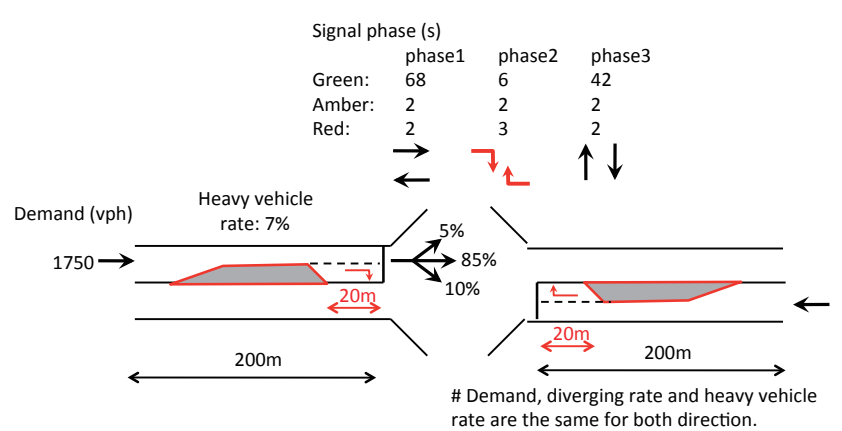

(b) With right-turn pocket

Fig.1 Geometry of artificial intersection 
(2) 交差点分岐率

上下線共に，右折 $10 \%$, 直進 $85 \%$, 左折 $5 \%$ とした。右折需要を高めに設定し，より交通混雑が顕著な交通 状態での評価を行うこととした。

(3) 右折車のギャップアクセプタンス

右折車両が右折実行の意思決定を行う場合、対向直進車との最小の車頭時間（以下、ギャップアクセプタンス） は 6s に設定した。これは，既存研究 (10)において妥当な現況再現性を得た場合の值である.

(4) 大型車混入率

比較的トラック輸送等の多い国道を想定し，上下線共に，一律 $7 \%$ とした。

(5) 信号現示

右折車線と青矢現示を設けない場合は，上下線共に青 $75 \mathrm{~s}$, 黄 $3 \mathrm{~s}$, 全赤 $3 \mathrm{~s}$, サイクル長 $129 \mathrm{~s}$ の定周期プリ夕 イムド制御とした。これらを設ける場合は，サイクル長は変化させず，上下線共に青 $68 \mathrm{~s}$ ，黄 $2 \mathrm{~s}$ ，全赤 $2 \mathrm{~s}$ ，青矢 青 $6 \mathrm{~s}$, 青矢黄 $2 \mathrm{~s}$ とした。青矢現示による損失分は全て上下線で吸収し, 従道路方向に影響を及ぼさぬものとした。

(6) 追従モデル

ドライバの追従モデルは既存研究 ${ }^{(11)}$ で既に用いられたものとし，そのパラメータは，国内テストコースにお ける走行実験で取得したデータから同定されたものを用いる。追従モデルとそのパラメータの現況再現性は妥当 であることが既存研究 ${ }^{(1)} に よ り$ 示されており, 日本人の追従挙動の再現性が確保されていると判断されるもの である. 式(1)に追従モデル式を示す。

$$
\ddot{x}(t+T)=a\left(\frac{v}{\ell} \cdot v^{\alpha}\right)+b\left(\sqrt[\delta]{\beta \cdot v^{\gamma}}-\frac{v}{\ell}\right)+c\left(\frac{R}{1+m \exp (n \cdot \ell)}-v\right)+\Phi
$$

ここに, $t$ : 時刻, $T$ : 車両反応時間, $\Delta v$ : 相対速度, $v$ : 自車速度, $\ell$ : 車間距離, その他は実測值から同 定するべきモデルパラメータとする，モデルパラメー夕は，乗用車，大型車でそれぞれ複数名の被験者により同 定された値を入力している ${ }^{(11)}$.

(7) シミュレーション実行パラメータ

1 回あたりのシミュレーション時間は $3600 \mathrm{~s}$, 各車両の加速度, 速度, 位置の計算ステップは $0.1 \mathrm{~s}$ とし, シミュ レーション終了時に, 交通需要発生地点から交差点通過までの 1 台あたりの平均旅行時間を出力する. 同時に, 右折成功時の対向直進車との平均車頭時間を計測し，これも 1 台あたりの平均值を出力する.ささらに, 上下線別 に CO2 の総排出量も計算し, 交通の円滑, 安全, 環境を定量的に評価することとする. 本研究の交通シミュレー 夕は確率的モデルであるため, 乱数により車両の発生タイミングをランダムに変化させ, 同じ条件でも乱数の異 なる 10 回のシミュレーションを行い，その平均值を計算することで，評価結果の一般化を図ることとした。

上記 (1) (7) ではいくつかのパラメー夕を仮定して与えた。例えば (5)については, 本研究は，右折車線長や 青矢現示の最適值を求めるものではなく, 大まかにかつ一般的に右折車優先行動による効果との比較を行うもの であるため，概ね滞留右折車が別けるようシミュレーションを繰り返して右折車線長 $20 \mathrm{~m} ，$ 青矢現示の青時間 を $6 \mathrm{~s}$ と設定した。

\section{3. 右折車優先行動のモデリングと評価方法}

\section{$3 ・ 1$ 右折車優先行動を行う対向直進車の混入}

右折車を優先する「利他的運転」を行う対向直進車は，右折車後方で進路をブロックされた車両台数（以下， 後続待ち台数）が増加するほどその混入割合が増えるように設定する。すなわち，対向直進車には後続待ち台数 の情報が何らかの形で与えら机ると仮定し，その情報に対して右折車を譲るか譲らないかの意思決定を確率的に 行わせ，後続待ち台数が多いほど右折車を譲る割合が増加する傾向とした。

図 2 は，この傾向をパターン（以下，pt.）に分けて示したものである，パターンの番号が増えるほど，概ね 後続待ち台数に対して右折車を譲る確率が増えることとなる。例えば, pt.8の方が pt.3 よりも累積確率は増加す るため, 右折車を譲りやすい行動であるといえる，後続待ち台数を $w$, 右折車を譲る確率を $y$ として, 10 パ夕ー ンのモデル式を式(2)に， $p_{a} \sim p_{f}$ のパラメー夕を表 1 に示す. 


$$
y=\left\{\begin{array}{l}
\exp \left(\frac{w}{p_{a}}\right) / p_{b} \\
p_{c} \\
p_{d} \cdot x \\
\frac{1}{1+p_{e} \exp \left(-p_{f} \cdot w\right)}
\end{array}\right.
$$

Table 1 Parameters for prioritizing right-turn vehicle

\begin{tabular}{|c|c|c|c|c|c|c|}
\hline pt. & $p_{a}$ & $p_{b}$ & $p_{c}$ & $p_{d}$ & $p_{e}$ & $p_{f}$ \\
\hline 1 & $\mathrm{n} / \mathrm{a}$ & $\mathrm{n} / \mathrm{a}$ & 0 & $\mathrm{n} / \mathrm{a}$ & $\mathrm{n} / \mathrm{a}$ & $\mathrm{n} / \mathrm{a}$ \\
\hline 2 & 2 & 1100 & $\mathrm{n} / \mathrm{a}$ & $\mathrm{n} / \mathrm{a}$ & $\mathrm{n} / \mathrm{a}$ & $\mathrm{n} / \mathrm{a}$ \\
\hline 3 & 3 & 82 & $\mathrm{n} / \mathrm{a}$ & $\mathrm{n} / \mathrm{a}$ & $\mathrm{n} / \mathrm{a}$ & $\mathrm{n} / \mathrm{a}$ \\
\hline 4 & 5 & 13 & $\mathrm{n} / \mathrm{a}$ & $\mathrm{n} / \mathrm{a}$ & $\mathrm{n} / \mathrm{a}$ & $\mathrm{n} / \mathrm{a}$ \\
\hline 5 & $\mathrm{n} / \mathrm{a}$ & $\mathrm{n} / \mathrm{a}$ & 0.5 & $\mathrm{n} / \mathrm{a}$ & $\mathrm{n} / \mathrm{a}$ & $\mathrm{n} / \mathrm{a}$ \\
\hline 6 & $\mathrm{n} / \mathrm{a}$ & $\mathrm{n} / \mathrm{a}$ & $\mathrm{n} / \mathrm{a}$ & 0.083 & $\mathrm{n} / \mathrm{a}$ & $\mathrm{n} / \mathrm{a}$ \\
\hline 7 & $\mathrm{n} / \mathrm{a}$ & $\mathrm{n} / \mathrm{a}$ & $\mathrm{n} / \mathrm{a}$ & $\mathrm{n} / \mathrm{a}$ & 40 & 0.7 \\
\hline 8 & $\mathrm{n} / \mathrm{a}$ & $\mathrm{n} / \mathrm{a}$ & $\mathrm{n} / \mathrm{a}$ & $\mathrm{n} / \mathrm{a}$ & 30 & 0.9 \\
\hline 9 & $\mathrm{n} / \mathrm{a}$ & $\mathrm{n} / \mathrm{a}$ & $\mathrm{n} / \mathrm{a}$ & $\mathrm{n} / \mathrm{a}$ & 50 & 1.4 \\
\hline 10 & $\mathrm{n} / \mathrm{a}$ & $\mathrm{n} / \mathrm{a}$ & 1 & $\mathrm{n} / \mathrm{a}$ & $\mathrm{n} / \mathrm{a}$ & $\mathrm{n} / \mathrm{a}$ \\
\hline
\end{tabular}

尚，「右折車の速度が $1 \mathrm{~m} / \mathrm{s}$ 以下で，かつ，右折車後方車両（自車）の加速度が $0 \mathrm{~m} / \mathrm{s}^{2}$ 以下で，かつ，自車直前 の車両との車間距離が $10 \mathrm{~m}$ 以内のとき，自車を右折待ち車両とする」と定義し，交通シミュレータ上で右折待 ち車両をオンラインで計測する. 右折車が発生する都度, pt.1 10のいずれかのモデル式を当てはめて, 対向 直進車が譲るか譲らないかの意思決定を確率的に行わせた。なお，式 (2) とそのパラメー夕は右折車を譲る割合 を段階的に変化させ，ほぼ全ての状況をまんべんなく表現するために染意的に与えたものであり，モデルや数值 を何らかの理論や経験則に基いて厳密に同定したものではないことを付記する.

\section{$3 \cdot 2$ 対向直進車の右折車優先行動モデル}

右折車を優先すると判断した対向直進車は，あたかも直近の信号現示が黄になって停止せざるを得ないという ように，自然な減速を開始するようにモデリングした。この時の対向直進車の加速度は，式 (1)において，車間 距離 $\ell$ を自車と停止線までの距離, 先行車の速度を 0 （相対速度 $\Delta v$ を $-v ）$ として計算する. 対向直進車の自

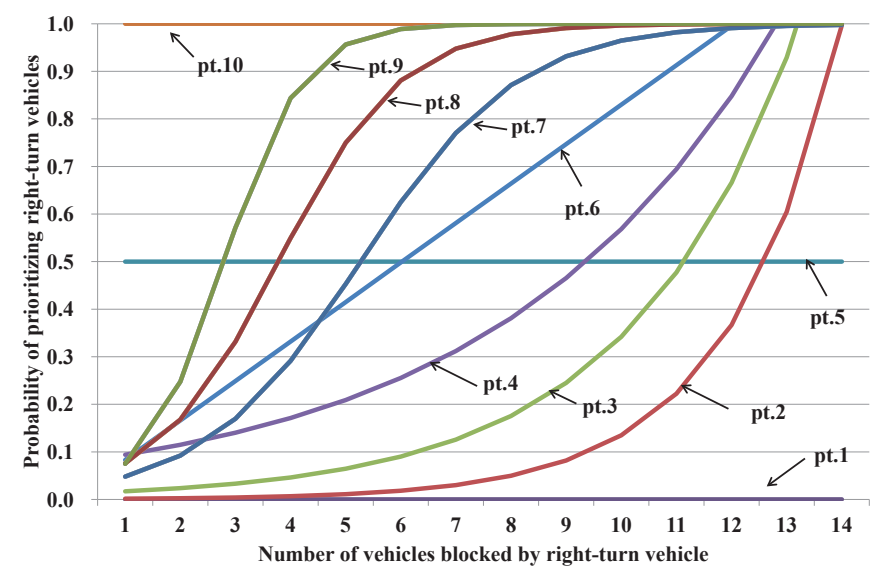

Fig.2 Ten probability density functions for prioritizing right-turn vehicle 
然な減速に伴って, 第2 章第2節の (3)で記述した右折車のギャップアクセプタンスが閾値を超える割合が増加し, 結果的に右折車が右折を成功させる機会が増加することとなる。

\section{$3 \cdot 3$ 右折車の右折行動モデル}

右折の意思決定を下した右折車の加速度は，他車と同様に式 (1)で決定する．この場合の車間距離 $\ell$ は $100 \mathrm{~m}$ とし，ほぼ自由流で加速するようにモデリングした。対向直進車が譲ってくれた場合でもそうでない場合でも加 速度決定式は同様とした。また，右折行動を開始した後，交差点を通過する間の制限速度は交差点以外の制限速 度より小さい值に設定した。対向直進車の右折車優先行動は，シミュレーションによる推計に大きな影響を及ぼ すものであるが, 本研究で用いたシミュレーションモデルは既に validation マニュアル(9) に沿って検証を済ませ, かつ現況再現性が確認された ${ }^{(10),(11)}$ モデルであることから, 右折車の右折行動モデルも妥当であると判断し評価 を行うこととした。

\section{$3 \cdot 4$ 交通の円滑の評価方法}

交通の円滑は，車両 1 台当たりの平均旅行時間で評価する。車両がリンクの始端を通過し，停止線を通過する までの旅行時間を 1 台ごとに計測し，シミュレーション時間内でこれを合計した後，トータルの通過台数でこれ を除して，1台あたりの平均旅行時間を計算する，実際の交差点では，右折待ち車両は停止線を超えていること が一般的であるが，本研究で用いたシミュレーションでは，右折待ち車両は停止線の手前で待機することになる 仕様であるため，直進車も右折車も同様に停止線通過までの旅行時間で評価を行う。旅行時間が長いほど円滑が 阻害されることを示す。式(3)に平均旅行時間の算出式を示す。

$$
\overline{t t m}=\sum_{i=1}^{N_{t}} t t m_{i} / N_{t}
$$

ここに, $\overline{\mathrm{ttm}}$ は平均旅行時間， $t t m_{i}$ は車両 $i$ の旅行時間， $N_{t}$ はそのリンクを通過した全車両台数である.

\section{$3 \cdot 5$ 交通の安全の評価方法}

交通の安全は，右折車が右折を成功させた時点での，右折車と対向直進車との平均車頭時間で評価する。一般 に，追従現象を扱う場合には車頭時間が用いられるが，ここでは右折車と対向直進車の先頭が衝突するまでの時 間を扱うため，車頭時間ではなく車頭時間とした，危険側の評価を適切に行うため，得られた車頭時間分布から が $14 \mathrm{~s}$ 以下の危険側のデータのみに着目し, このデータのみで 1 台あたりの車頭時間の平均值を求めることとし た。車頭時間が小さいほど危険性が高いことを示す。式(4)に平均車頭時間の算出式を示す.

$$
\overline{t h w}=\sum_{i=1}^{N_{s}} t h w_{i} / N_{s}
$$

ここに, $\overline{t h w}$ は平均車頭時間， $N_{s}$ は右折を成功させた右折車の台数， $t h w_{i}$ は右折成功時の右折車 $i$ と対向 直進車との車頭時間であり，次式で計算する.

$$
t h w_{i}=x_{r}^{i}+x_{r}^{i}+x_{c} / v_{d}^{i}
$$

ここに， $x_{r}^{i}$ 及び $x_{d}^{i}$ は右折車 $i$ 及びそれに対する対向車の停止線までの距離， $x_{c}$ は上下線の停止線間の距離で ある。なお，本研究では $x_{c}$ を一般的な值として $15 \mathrm{~m}$ に設定した。

\section{$3 \cdot 6$ 交通の環境の評価方法}

交通の環境は，(財）石油産業活性化センターが開発した排出ガス排出量の計算方法を用いて，上下線の道路 リンクを通過した全車両の $\mathrm{CO} 2$ 排出量を積算することで評価する ${ }^{(12)}$. 車両 1 台ごとの $\mathrm{CO} 2$ 排出量を計算する ために，まず，交通シミュレー夕から得られる車両の加速度と速度から，車両の駆動力を次式で求める.

$$
F R C=(1+\theta) \times V W \times \frac{A C C}{3.6} \times R C \times V W \times 9.80665 \times S S+F S \times 9.80665 \times V E L^{2}
$$


ここに, $F R C$ : 駆動力 $(\mathrm{N}), V W$ : 車重 $(\mathrm{kg}), A C C$ : 加速度 $\left(\mathrm{m} / \mathrm{s}^{2}\right), R C$ : 転がり抵抗係数, $S S$ : 道路勾配, $F S$ :車両前面投影面積, $V E L$ :速度 $(\mathrm{km} / \mathrm{h}), \theta$ : 回転部相当慣性重量比率である. 今回のシミュレーションでは, 道路勾配はないものとした，次に，図 3 に示す 2 次元の排ガスマップ上で，ある瞬間の駆動力と速度に該当する $\mathrm{CO} 2$ 排出量を求め，これを時間と空間で積み重ねることで道路空間上に積算される $\mathrm{CO} 2$ 排出量を計算する。例 えば駆動力が $1500 \mathrm{~N} ，$ 速度が $50 \mathrm{~km} / \mathrm{h}$ の時の CO2 排出量は図 3 ののの位置 $7.02 \mathrm{~g} / \mathrm{s}$ と読み取れる.

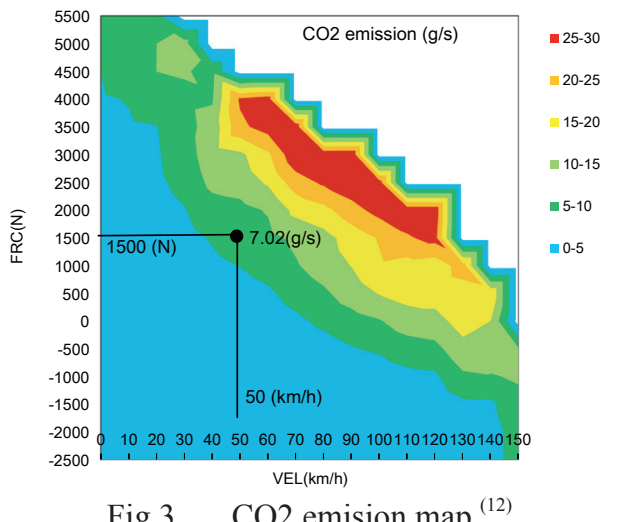

\section{4. 交通シミュレータによる評価結果}

\section{$4 \cdot 1$ 円滑の評価結果}

図 4 (a) (b) は，それぞれ上下線の旅行時間を 5 ケースの交通需要と 10 パターンの譲り行動で比較したもので ある。これらの図から，右折車を譲りやすい行動を行うほど上下線共に旅行時間が減少しており，譲った側も譲 られた側もお互いが得をする傾向にあることがわかる。また，旅行時間減少効果は $250 \mathrm{vph}$ の小さ交通需要で は全く認められないものの，500vph で既に顕著になり始め，比較的小さい交通需要でも右折率が $10 \%$ と顕著な 交通渋滞が発生する状況では，右折車優先の効果が認められることがわかる。ここで，例えば Pt.2 と Pt.3の比 較に代表されるように必ずしも優先確率が高いほうが高い効果が得られるとは限らない場合もあるが，これは， 同じ条件でも 10 回のトライアルの中で、例外的に高いあるいは低い数值が生じることが主な原因と考元れる。. 確率的なシミュレーションである以上，車両の発生頻度や右折車の発生夕イミング等によっては同じ条件でも交 通状況に顕著な差が生じ，その結果旅行時間にも顕著な変化が生じるため，このバラツキを一般化するために 10 回のトライアルの平均值で判断することとした。

当初は，右折車優先の効果が出始める時のパターンを見つけるために感度分析を行うこととしたが，結果的に は，pt.2のように，10パターンの中では最も襄りにくい状況であっても効果は顕著になり始めるという結果が 得られた。ささに，旅行時間の減少はいずれかのパターンで飽和する傾向にはなく，ほぼ直線的に効果が得られ ることもわかった。本稿では全体的な傾向を把握することを主眼におくため，この理由を詳細に検証することは

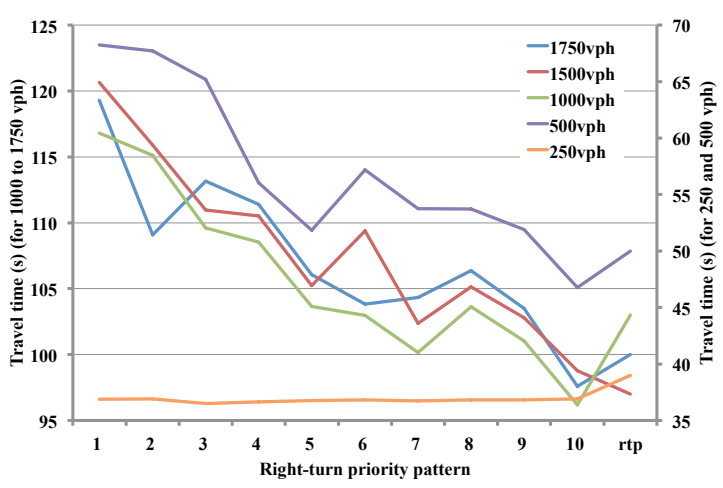

(a) Inbound

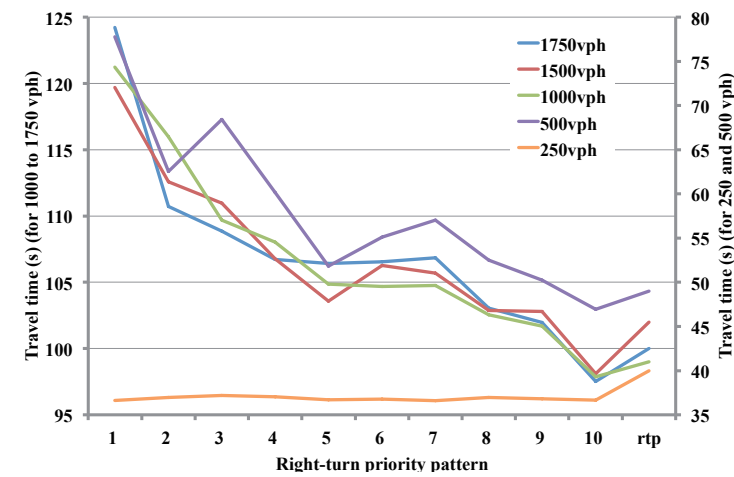

(b) Outbound

Fig.4 Travel time comparison among 10 patterns of prioritization 
本稿の範囲外としたが，信号制御に伴って効率的に利用されずに余っていた時空間が比較的大きいと考えられる ため，右折車優先行動を行えば行うほどこの時空間をより多く効率的に利用でき，この結果直線的に旅行時間が 減少するものと推察される。

図 5 (a) (b) は，pt.1 の旅行時間を 1.0 としたときの旅行時間増加率を上下線で比較したものである. 旅行時間 の減少は，上下線とも交通需要 500vph の時が最も顕著であるように思われる。また，図 5 (a) の上り線では，交 通需要が増加するに従って減少率が目減りする，すなわち交通需要が多いほど効果は減少することがわかるが， 図 5 (b) の下り線では逆に効果は概ね増加傾向にある。これは, 上り線の効果が大きい分, 下り線の効果は小さ くなるというトレードオフの関係に起因するものと考えられる。ただし，本研究で用いた交通シミュレータは確 率的なモデルであるため，上下線で同じ交通需要や同じ右折率であっても，発生車両や右折車両の発生夕イミン グは上下線で異なることから，必ずしも上下線で同等の旅行時間が得られるわけではないことを付記する。

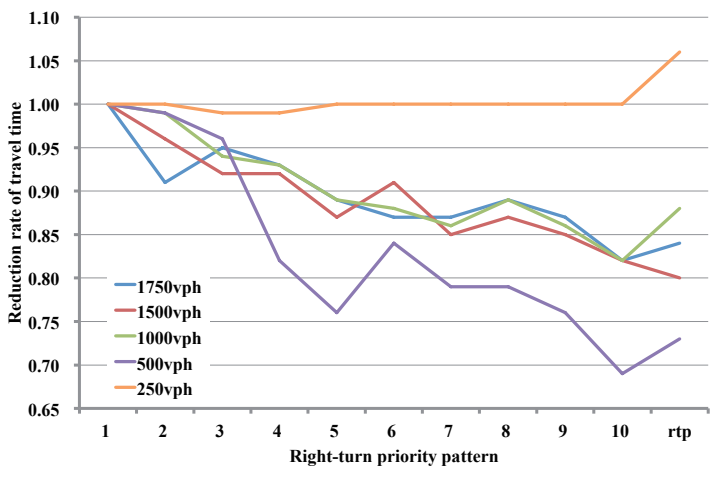

(a) Inbound

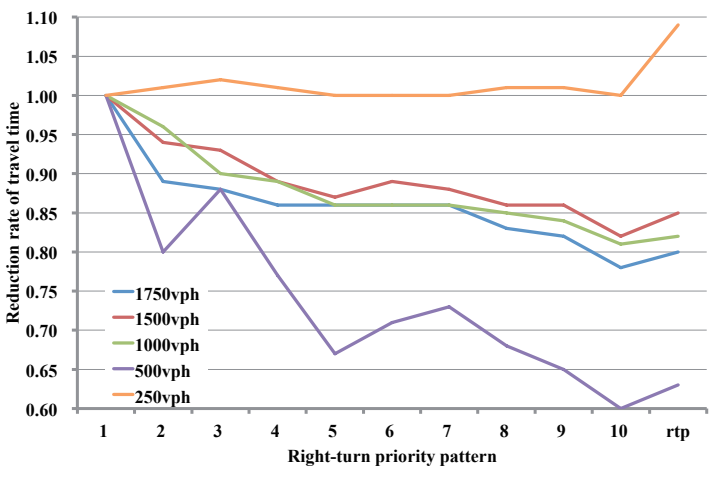

(b) Outbound

Fig.5 Comparison of reduction of travel time (pt.1=1.0)

\section{$4 \cdot 2$ 安全の評価結果}

図 6 (a) (b) は，上下線別の右折成功時の車頭時間を比較したものである. 交通需要 250vph の場合を除き, 右 折車を譲りやすい行動を行えば行うほど，右折成功時の車頭時間は増加し，対向直進車との衝突に対して時間的 な余裕を持って右折を完了させられることがわかる，右折優先行動では対向直進車が減速を行うため，車頭時間 が増加するのは当然の結果と言える．旅行時間の評価結果と同様，pt.2 のように，10 パターンの中では最も譲 りにくい状況であっても，車頭時間の増加効果は顕著であることも理解できる.

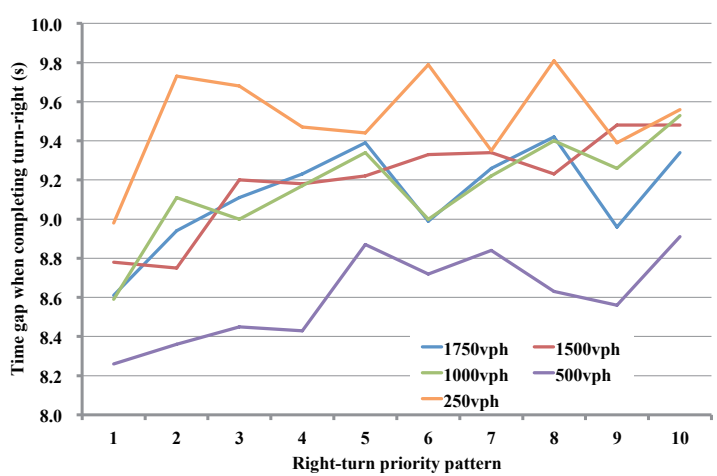

(a) Inbound

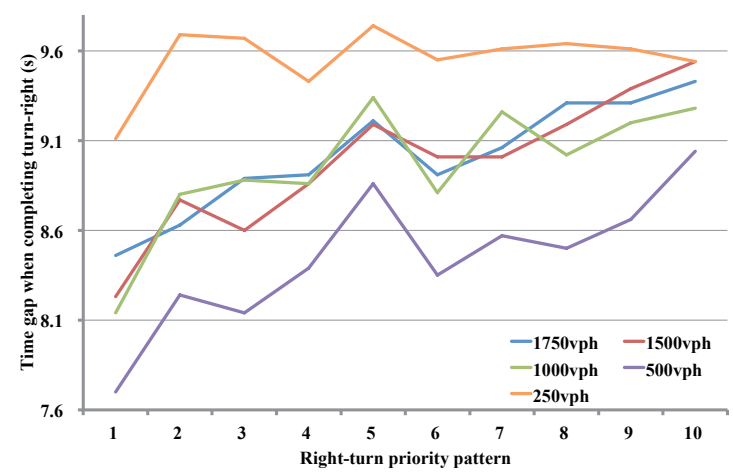

(b) Outbound

Fig.6 Comparison of average time headway when completing right-turn

\section{$4 \cdot 3$ 環境の評価結果}

図 7 (a) (b) は，環境の評価結果として，上下線別の $\mathrm{CO} 2$ 総排出量を比較したものである。右折車を譲りやす い行動で旅行時間が減少すると平均車速は増加し, 低車速域で CO2 排出量の大きい部分での走行が減少するた め, $\mathrm{CO} 2$ 総排出量は減少する結果となった。 円滑や安全の評価結果と同様に，この傾向が成り立つのは交通需 要が 500vph 以上の場合であり, 交通需要がそれよりも小さい場合には顕著な交通渋滞が発生していないため, 譲り行動を変化させても $\mathrm{CO} 2$ 総排出量に変動は無い. 


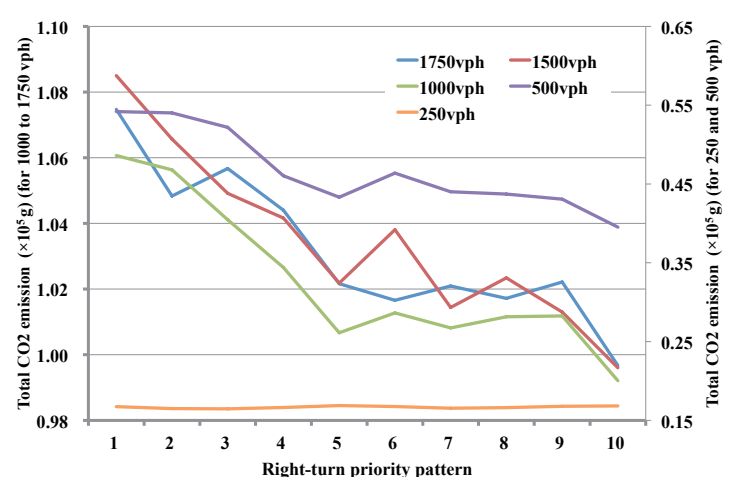

(a) Inbound

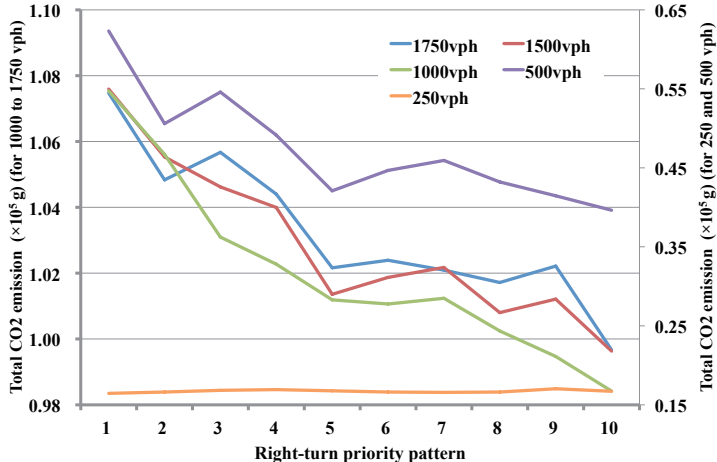

(b) Outbound

Fig.7 Comparison of $\mathrm{CO} 2$ emission among ten prioritizing pattenrs

\section{$4 \cdot 4$ 右折車線及び青矢現示の設置との比較}

これまでの解析結果から，右折車優先行動は交通の円滑性向上に寄与するために，環境負荷も軽減され，かつ 右折車が安全に右折を成功させられる効果があることが評価できた。この傾向は定性的な傾向であることが理解 できたため, ここでは交通の円滑のみに着目し，右折車線及び青矢現示を設けた場合との比較結果を説明する。

図 4 5の右端（図中で rtp と表記）は，右折車線及び青矢現示を設置した場合の旅行時間とその減少率を， 5 ケースの交通需要で比較したものである。いずれの交通需要でも, 必ず右折車を優先させるパターン 10 より も旅行時間は増加する傾向にあることが理解できる，また，このことから，右折車優先行動はその譲り方によっ て効果は異なるものの，概ね，右折車線及び青矢現示設置と同等あるいはそれ以上の効果が発揮されることが示 された。

\section{$4 \cdot 5$ 右折車優先行動が上下線で異なる場合}

図 4〜 7 の結果は，設定した右折車優先行動を上下線で同時に行った場合の結果であるが，現実的には上下線 のいずれか一方だけが右折車優先行動を行う場合も考えられる。そこで，表 2 に示すように，上下線で異なる右 折車優先行動を 5 ケース設定した場合, 譲られた側と譲る側でその効果にどのような差があるが検証した。この 時の交通需要は $1750 \mathrm{vph}$ とし, 最も混雑の顕著な状況のみを対象とした。ここで, 上下線でいずれも右折車優 先行動を行わない場合をリファレンス（ケース0）として5ケースを評価した.

Table 2 Different prioritizing patters for inflow direction

\begin{tabular}{|c|c|c|c|c|c|c|}
\hline cases & 0 & 1 & 2 & 3 & 4 & 5 \\
\hline inbound & pt.1 & pt. 1 & pt. 2 & pt. 3 & pt. 4 & pt. 5 \\
\hline outbound & pt.1 & pt. 10 & pt. 9 & pt. 8 & pt. 7 & pt. 6 \\
\hline
\end{tabular}

この評価結果を図 8 に示す。同じ条件で乱数を 10 パターン発生させた時の旅行時間の平均值を示している. まずケース 1 は, inbound（上り）は相手を全く譲らずに（pt.1）自分だけが常に譲られ，かつ， outbound（下り） は逆に自分は全く譲られないが，常に相手を譲る (pt.10) ケースである. リファレンスのケース 0 と比べ, 常に 襄られるだけの上りの旅行時間は顕著に減少するが，常に譲るだけの下りの旅行時間は全く変化はない.すなわ ち, どちらか一方が譲るだけでは譲られた側だけが得をして, 譲る側には恩恵はないことがわかる，ただし，譲 るだけの側であっても，旅行時間がリファレンスより増加することはなく，少なくとも損はしていないことがわ かる。しかし, 相手との相対的な感覚では旅行時間は増えていることから, 譲った側のドライバが損をしたよう に感じる可能性は十分考えられる。

ケース 2〜 5 に進むにつれて, 上りの譲る割合が増加し, かつ下りの譲られる割合も増加すると, リファレン スと比較して両方向とも恩恵を受ける結果となる。 上下線が譲る行為と譲られる行為をお互いに実行しなければ 交差点全体としての正の効果は得られないことがわかる. 


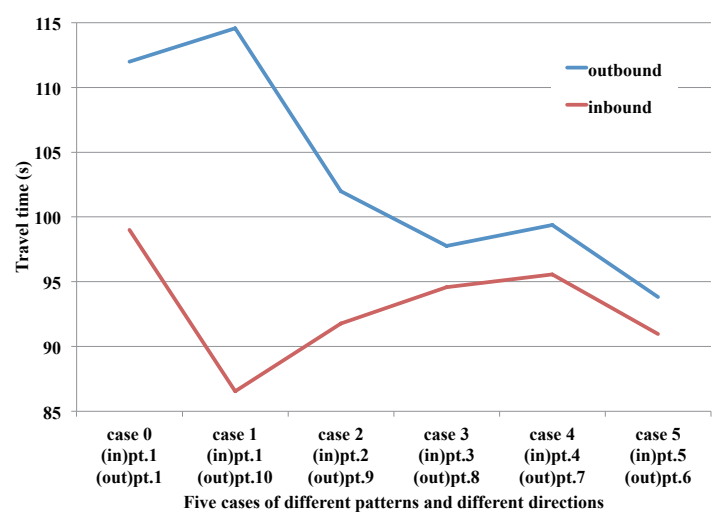

Fig.8 Travel time for different prioritizing pattenrs and directions

5. 結 語

今回，「交差点では直進車優先」という現状の運用方法に対して，敢えて対向直進側のドライバが右折車に通 行権（right-of-way）を譲る「利他的運転」に着目し，どの程度の交通需要でどのような譲り方をすると，交通 の円滑, 安全, 環境にどの程度の効果が表れるかを検討した。また，一般的な右折専用車線や右折専用現示を設 けた場合と比較し，その効果の相対的な位置関係を把握することとした。仮想の交差点で交通シミュレー夕を用 いた感度分析を行った結果，以下の知見が得られた。

(1) 常に全ての右折車を譲るという極端な利他的運転でなくとも, 小さい確率で右折車を譲ることで, 譲つ た側も譲られた側も旅行時間と CO2 排出量の減少効果，右折成功時の車頭時間の増加効果が得られる。

（2）右折車を譲る確率を増加させる程，すなわちその累積確率が大きい程，ほぼ直線的に旅行時間と CO2 排出量の減少，右折成功時の車頭時間の増加効果が得られ，ぞこかで飽和することがない。

(3) 極端に小さい交通需要での右折車優先行動は効果が認められないが，右折率が高い状況では，交通需要 が比較的小さくとも，円滑，安全及び環境の改善に顕著な効果がある.

（4）右折車優先行動は，右折車を優先する確率が比較的高い場合に限っては，概ね，右折車線及び青矢現示 の設置と同等あるいはそれ以上の交通の円滑効果がある。

（5）上下線のうち片方のみが譲る行動を行なうと, 譲られた側のみが旅行時間が減少し, 譲る側は旅行時間 が増加して損をすることになる．譲る側の旅行時間の増加はあまり顕著ではないものの，上下線で譲る 行為と譲られる行為の両方を行わなければ交差点全体としての効果は得られない.

以上の知見から, 交通需要が多い, あるいは右折率が高いなどの理由で後続待ち台数が存在するようであれば, 積極的に右折車優先という「利他的運転」を行うことで, 右折車線や青矢現示の設置など, 従来の土木・交通工 学的なインフラ改良に依存せずとも, 人間が本来所有する譲り合いの精神という人間工学的なアプローチで交通 システム全体の改善効果が得られる可能性を見出すことができた。本稿では，右折車線長や青矢現示の長さは必 ずしも最適な值を算出した訳ではないが，大まかに右折車優先による効果はインフラ改良と比較して十分な効果 が得らることが示唆された。この結果により, 少しでも右折車を優先するという利他的運転の動機づけをドライ バに促すための，自動車側での HMI を検討する意義を認めることができた.

ただし，本稿でのモデリングは未だ比較的粗い全体的な評価に留まっていることも事実である，例えば，対向 直進車の後続にどの程度の車両が存在するか，また，対向直進車から見て右折車との夕イムギャップが長いか短 いかによって対向直進車の優先行動が変化することが現実的であるが, この部分のモデリングは行なっていない. 今後, 実際の交差点を評価対象とした厳密な推計を行う場合にはこのようなモデリング必要不可欠であると考元 られる.さらに，後続待ち台数の情報に対するドライバの意思決定行動を調査し，右折優先行動を促す HMI を 検討することも必要である。この際, ドライバが「譲られた」と認識するための配慮や, 譲る行為で損をするこ とはないことをどのように伝えドライバ受容性を確保するかについても議論が必要である.

最後に，本研究の数值計算では 2011 年度日本工業大学卒業生の丹羽雄一君の協力を得ると共に，(財）日本自 動車研究所から追従走行データ，(財）石油産業活性化センターから CO2 排出マップと排ガス計算プログラムを 提供戴いた。記して謝意を表する。 


\section{文献}

（1）芳賀繁，”安全技術では事故を減らせないーリスク補償行動とリスクホメオスタシス理論—”，電子情報通信学会 技術研究報告＼cjkstart信学技報，Vol.109, No.151 (2009), pp. 9-11.

(2) 丸茂喜高, ”自動車の運転支援システムが目指すべき姿について”, 電子情報通信学会技術研究報告 信学技報, Vol. 109, No. 151 (2009), pp. 17-20.

(3) 例えば，平岡敏洋, 寺門康弘, 松本修一, 山邊茂之, ”エコドライブ走行の教示内容および燃料消費量計の提示が 燃料消費率低減効果に与える影響”, ヒューマンインタフェース学会論文誌, Vol.12, No.1 (2010), pp.71-80 など。

（4）丸茂喜高，鈴木宏典，片山硬，" 対向右折車への優先行動が交通流へ及ぼす影響 ", 計測自動制御学会論文誌, Vol. 48, No. 10 (2012)（掲載予定）.

（5）吉川康雄，森田育宏，香月伸一，羽藤英二，貴志 泰久，“市街地交通予測のためのミクロ交通流シミュレータの 構築（TRAF-NETSIM の国内交通への適用性の検討および路上駐車車両影響モデルの開発）“，日本機械学会論文 集B編，Vol. 63，No. 610 (1997)，pp. 2252-2258.

(6) 山本直史，森下信，“セルラオートマトンによる交通流のモデル化とその制御”，日本機械学会論文集C編，Vol. 65, No. 637 (1999), pp. 3553-3558.

(7) 井口智彦, 脇田佑希子, 清水光輝, 玉城龍洋, 北栄輔, “多追従モデルを用いた道路合流部における沙滞の緩和”, 日本機械学会論文集C編，Vol. 75，No. 758 (2009)，pp. 2695-2702.

（8）倉田真吾，村松将邦，長谷隆，“隊列走行による交通流の安定化と促進 “，日本機械学会論文集 B編，Vol. 67, No. 660 (2001), pp. 2019-2026.

（9）（社）交通工学研究会交通シミュレーション自主研究委員会，”交通流シミュレーションの標準検証プロセス -Verification マニュアル -” (2001), p. 51.

(10) 鈴木宏典, 鈴木忠, ”道路環境評価を目的とした交通流シミュレーションモデルの現況再現性検証”, 自動車研究, Vol.27 No.5 (2005), pp. 189-192.

（11）鈴木宏典，藤井健，福島正夫，”追従走行シミュレーションを用いた実幹線道路における乗用車と大型車の混在 車群の安全性評価”, 自動車技術会論文集, Vol.42, No.4 (2011), pp. 961-966.

(12) (財) 石油産業活性化センター, ”JCAP II 沿道自動車排出量推計システム”, (2007). 